\title{
Histological and Histochemical Studies of the Aorta and Pulmonary Trunk in STZ-induced Diabetic Wistar Rats Treated with Momordica charantia
}

\author{
Estudio Histológico e Histoquímico de la Aorta y el Tronco Pulmonar en Ratas \\ Wistar Diabéticas Inducidas por STZ y Tratadas con Momordica charantia
}

\author{
O. A. Komolafe"; D. A. Ofusori"; O. S. Adewole*; A. O. Ayoka** \& R. Bejide****
}

KOMOLAFE, O.A.; OFUSORI, D. A.; ADEWOLE, O. S.; AYOKA, A. O. \& BEJIDE, R. Histological and histochemical studies of the aorta and pulmonary trunk in STZ-induced diabetic wistar rats treated with Momordica charantia. Int. J. Morphol., 31(2):716-723, 2013.

SUMMARY: Diabetes mellitus (DM) is a serious metabolic disorder with micro and macro-vascular complications that result in a significant morbidity and mortality. The present study investigated the effects of Momordica charantia (M. charantia) on histological changes of the aorta and pulmonary trunk in streptozotocin-induced diabetic Wistar rats. Forty healthy adult Wistar rats of both sexes were randomly assigned into five groups A, B, C, D and E of eight rats each. Group A were the control (normal rats); B were the experimentallyinduced diabetic rats; $\mathrm{C}$ were diabetic rats treated with methanolic extracts of $M$. charantia for two weeks (withdrawal group); D were diabetic rats treated with methanolic extracts of M. charantia for four weeks. E was diabetic rats treated glimepiride for four weeks. Tissues were harvested, processed routinely in paraffin wax and stained with routine and special stains. Histological results revealed morphological alterations in the aorta and pulmonary trunk of diabetic rats. Histochemical analysis also revealed abnormal deposition of glycogen in these vessels of diabetic rats. $M$. charantia and glimperide attenuated the morphological alterations and reduced the glycogen deposits. In conclusion M. charantia has a promising ameliorative effect on the morphology of the aorta and pulmonaty trunk in STZ-induced diabetic wistar rats and by extension, may be relevant in the management of cardiovascular alteration associated with DM.

KEY WORDS: Diabetes; Momordica charantia; Histological; Histochemistry; Aorta; Pulmonary trunk.

\section{INTRODUCTION}

Diabetes mellitus (DM) is a serious metabolic disorder with micro and macro-vascular complications that result in a significant morbidity and mortality. Increasing proportion of the aging population, consumption of calorie rich diet, obesity and sedentary lifestyle have led to a tremendous increase in the number of diabetics worldwide (Vats et al., 2004). Diabetic patients are particularly prone to cardiovascular diseases including hypertension, atherosclerosis, diabetic cardiomyopathy, congestive heart failure and cardiac autonomic neuropathy (Jarret, 1989). Coronary atherosclerosis and cardiomyopathy occur as a result of the metabolic abnormalities associated with diabetes (Grundy et al., 1999). These physical changes require years to develop in human following the onset of chronic hyperglycemia (The Diabetes and Complications Trial
Research Group, 1993). Studies have shown that cardiac function is altered after six months of hyperglycemia in Wistar rats (Malone et al., 1999).

Momordica charantia (Linn Family: Cucurbaceae) is one of the popular herbs that grow in different regions of Nigeria. It is commonly called Bitter melon, Bittergoud, Balsam pear. Bittergourd is known in some tribes of Nigeria as Ejirin wewe (Yoruba) Okban, Ndeme (Igbo) and Garafun (Hausa). It's a slender, climbing annual vine with long-stalked leaves and yellow, solitary male and female flowers borne in the leaf axils. The fruit looks like a warty gourd, usually oblong and resembling a small cucumber. The young fruit is emerald green, turning to orange-yellow when ripe. At maturity, the fruit splits into three irregular valves that curl

\footnotetext{
* Department of Anatomy and Cell Biology, Faculty of Basic Medical Sciences, Obafemi Awolowo University, Ile-Ife, Osun-State, Nigeria.

** Department of Physiological Sciences, Faculty of Basic Medical Sciences, Obafemi Awolowo University, Ile-Ife, Osun-State, Nigeria.

****Department of Morbid Anatomy and Forensic Medicine, Faculty of Basic Medical Sciences, Obafemi Awolowo University, Ile-Ife, Osun-State, Nigeria.
} 
backwards and release numerous reddish-brown or white seeds encased in scarlet arils. The Latin name Momordica means "to bite," referring to the jagged edges of the leaves, which appear as if they have been bitten. All parts of the plant, including the fruit, taste very bitter (Braca et al., 2008).

Various parts of $M$. charantia such as the seed, fruit and even the whole plant has been reported to have beneficial effects in prevention and treatment of many diseases in folkloric medicine, especially in the treatment of DM in individuals with non-insulin dependent diabetes (Platel \& Srinivasan, 1997; Raman \& Lau, 1996). It has hypoglycaemic properties as it significantly suppressed the rise in blood glucose concentrations in albino rats (Platel \& Srinivasan; Nicholas et al., 2006). The first clinical study into the influence of the fresh juice of bittergourd on the management of DM was by Akhtar (1981). These findings suggested the intervention would effectively treat all symptoms of diabetes including polyuria, polydipsia, and polyphagia. Sarkar et al. (1996) and Miura et al. (2001) indicated that the fresh bitter-gourd juice caused a significant reduction in plasma glucose concentration, and an improvement in the response to an oral glucose load. Bitter melon contains an array of biologically active plant chemicals including triterpenes, proteins and steroids. In addition, a protein found in bitter melon, momordin, has clinically demonstrated anticancerous activity against Hodgkin's lymphoma in animals. Other proteins in the plant, alpha- and beta-momorcharin and cucurbitacin B, have been tested for possible anticancerous effects. (Nagasawa et al., 2002). In numerous studies, at least three different groups of constituents found in all parts of bitter melon have clinically demonstrated hypoglycemic (blood sugar lowering) properties or other actions of potential benefit against diabetes mellitus (Tan et al., 2007). These chemicals that lower blood sugar include a mixture of steroidal saponins known as charantins, insulin-like peptides, and alkaloids. The hypoglycemic effect is more pronounced in the fruit of bitter melon where these chemicals are found in greater abundance.

The present study investigated the effects of $M$. charantia on histological and histochemical changes of the aorta and pulmonary trunk in streptozotocin-induced diabetic Wistar rats and compared the effects with those of glimepiride, an oral blood-glucose-lowering drug of the sulfonylurea class.

\section{MATERIAL AND METHOD}

Animal care. Forty healthy adult Wistar rats of both sexes, with average weight of $134.4 \mathrm{~g}$ were used for the experiment. The rats were bred in the animal holding of College of Health Sciences, Obafemi Awolowo University, Ile-Ife. They were maintained on standard rat pellet (Capsfeed, Ibadan, Nigeria) and water was provided ad libitum.

The animals were randomly assigned into five groups A, B, C, D and E of eight rats each.

- Group A were the control (normal rats)

- Group B were the experimentally-induced diabetic rats administered with $10 \%$ tween 80 .

- Group $\mathrm{C}$ were the experimentally-induced diabetic rats treated with methanolic extracts of Momordica charantia dissolved in $10 \%$ tween 80 for two weeks (withdrawal group) - Group D were the experimentally-induced diabetic rats treated with methanolic extracts of Momordica charantia dissolved in $10 \%$ tween 80 for four weeks.

- Group E were the diabetic rats treated with a standard diabetic drug $(2 \mathrm{mg} / \mathrm{kg}$ of glimepiride) dissolved in $10 \%$ tween 80 for four weeks.

The animals received humane treatment as outlined in the "Care and Management of Laboratory Animals" published by the National Institute of Health.

Plant material. Matured leaves of Momordica charantia (Cucurbitaceae) were collected during the raining season from suburban villages of Ile-Ife metropolis in Osun State of Nigeria. The leaves were taken to the Herbarium in the Department of Botany, Obafemi Awolowo University, IleIfe to confirm identification and a voucher specimen number (UHI 16510) was placed in the Herbarium.

Preparation of methanolic extract of $M$. charantia. Leaves of Momordica charantia were air dried and powdered in a warring blender. A $765 \mathrm{~g}$ of the powdered leaves were extracted in $1.950 \mathrm{ml}$ of absolute methanol for 72 hours with intermittent shaking and filtered. The filtrate was concentrated in vacuo at $35^{\circ} \mathrm{C}$ using a vacuum rotary evaporator (Büchi Rotavapor R110, Schweiz). The extract were partitioned between water and dichloromethane, the dichloromethane fraction (5.94\%) was oven-dried at $37^{\circ} \mathrm{C}$ and stored until it is ready to be used. The aqueous portion obtained was very little. Aliquot portions of the extract were weighed and dissolved in $10 \%$ tween 80 for use on each day of the experiment.

Induction of diabetes. Diabetes mellitus was experimentally induced in groups B, C, D and E by a single intraperitoneal injection of $65 \mathrm{mg} / \mathrm{kg}$ body weight of streptozotocin (Tocris Bioscience, UK) dissolved in $0.1 \mathrm{M}$ sodium citrate buffer (pH 6.3). Diabetes was confirmed in animals 48 hours after 
induction, by determining fasting blood glucose level using a digital glucometer (Accu-chek ${ }^{\circledR}$ Advantage, Roche Diagnostic, Germany) consisting of a digital meter and the test strips using blood samples obtained from the tail vein of the rats. Animals in-group A were given equal volume of citrate buffer used in dissolving streptozotocin intraperitoneally.

Administration of extract and anti-diabetic drug. Methanolic extracts of the leaves of M. charantia $(100 \mathrm{mg} /$ $\mathrm{kg}$ ) was dissolved in $10 \%$ tween 80 and administered daily (orally) by gastric intubation to the rats in groups $\mathrm{C}$ and $\mathrm{D}$ for 2 and 4 weeks respectively. The standard antidiabetic drug (glimepiride $2 \mathrm{mg} / \mathrm{kg}$ ) was administered to group E rats for four weeks (Mir et al., 2008), while those in group B were left untreated.

Sacrifice of the animals. At the end of the experimental period, all the animals were physically observed and anesthesized by chloroform inhalation. A midline incision was performed at the thoracic region. The vessels (aorta and pulmonary trunk) were dissected out, fixed in $10 \%$ Formol saline and $10 \%$ neutral buffered formalin for 48 hours.

Histology, Histochemistry and Photomicrography. Tissues were processed routinely in paraffin wax embedding.
Sections of $6 \mu \mathrm{m}$ thick were cut and stained H-E procedure, Verhoeff - Van Gieson (VVG) staining procedure for elastic fibre and Periodic Acid Schiff (PAS) staining procedure for demonstration of glycogen. The sections were examined under a LEICA research microscope (LEICA Dm750, Switzerland) with a digital camera attached (LEICA ICC50). Digital photomicrographs of stained sections were taken.

\section{RESULTS}

Histological results revealed that there were gradual deposition of lipid in the tunica intima of the aorta and pulmonary trunk in untreated diabetic state. These alterations were reduced with the administration of $M$. charantia and glimepiride for four weeks. Withdrawal of extract treatment only showed mild improvement in the histological outline as shown in (Figs. 1 and 2). Evidence from Verhoeff's van Gieson stain showed a reduction in the elastic fibers in the tunics of the aorta and pulmonary trunk in the diabetic group. With the administration of $M$. charantia and glimepiride for four weeks, there was significant improvement in the deposition of elastic fibers as evident in the intense staining intensity. Withdrawal of extract treatment slightly improves the deposition of elastic fibers (Figs. 3 and 4). Histochemical

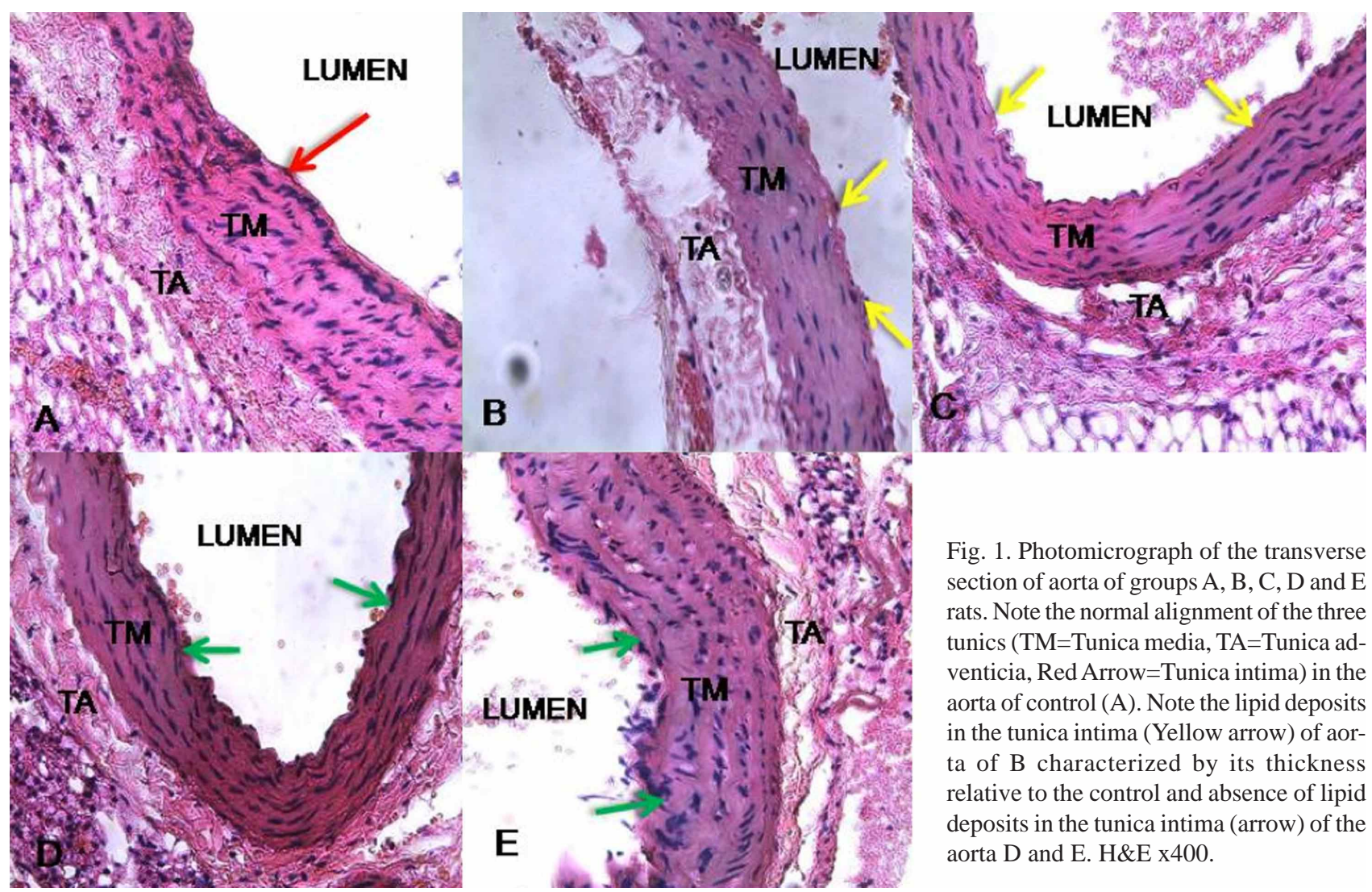


findings showed accumulation of glycogen deposit in aorta and pulmonary trunk of diabetic rats. Treatment of diabetic rats with $M$. charantia and glimepiride for four weeks reduced the Periodic Acid Schiff (PAS) positive staining intensity. The group treated with $M$. charantia for two weeks, only revealed a mild reduction in the PAS positive staining intensity as shown in Figures 5 and 6.
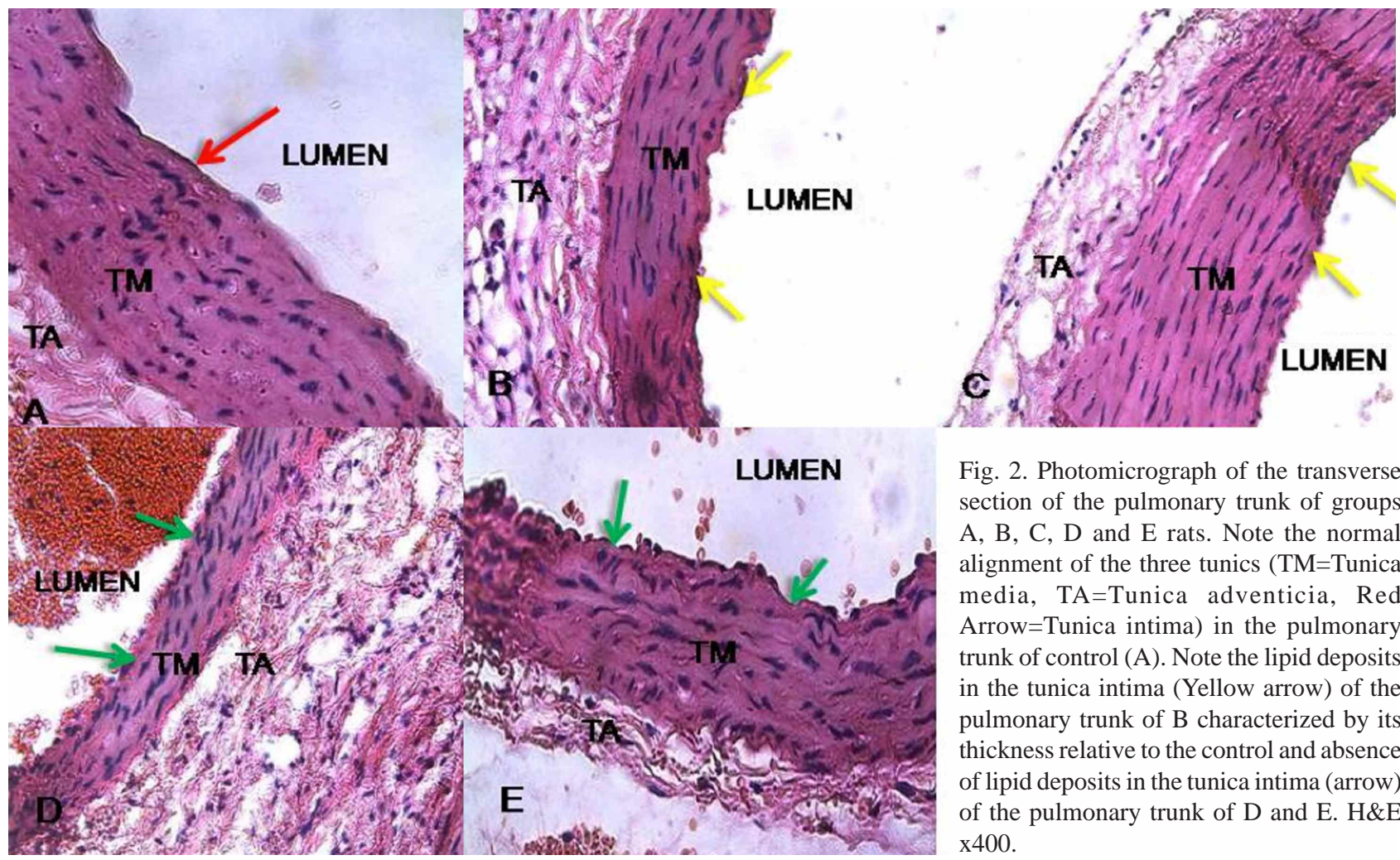

Fig. 2. Photomicrograph of the transverse section of the pulmonary trunk of groups A, B, C, D and E rats. Note the normal alignment of the three tunics (TM=Tunica media, TA=Tunica adventicia, Red Arrow=Tunica intima) in the pulmonary trunk of control (A). Note the lipid deposits in the tunica intima (Yellow arrow) of the pulmonary trunk of B characterized by its thickness relative to the control and absence of lipid deposits in the tunica intima (arrow) of the pulmonary trunk of D and E. H\&E $\mathrm{x} 400$.
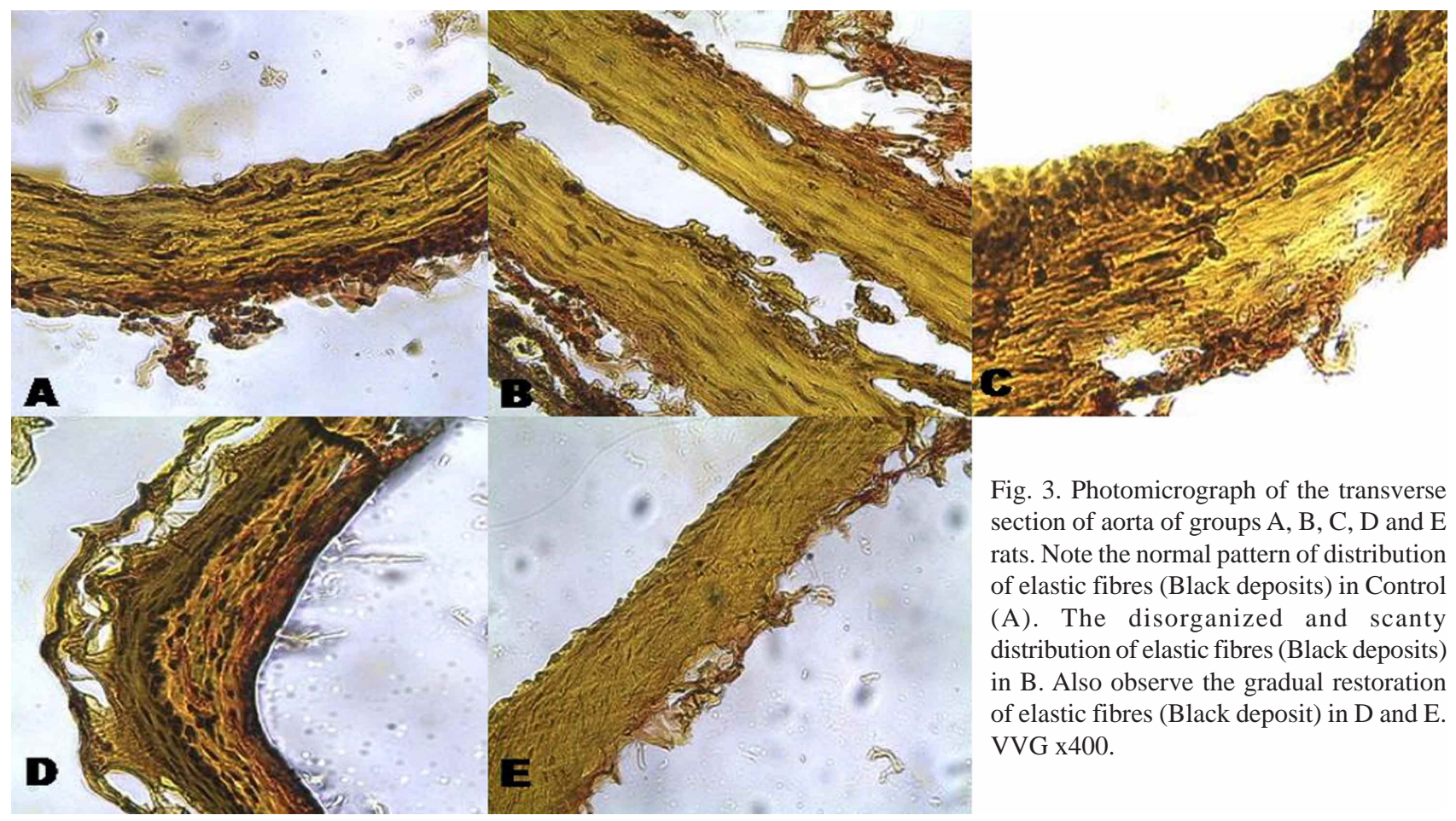

Fig. 3. Photomicrograph of the transverse section of aorta of groups A, B, C, D and E rats. Note the normal pattern of distribution of elastic fibres (Black deposits) in Control (A). The disorganized and scanty distribution of elastic fibres (Black deposits) in B. Also observe the gradual restoration of elastic fibres (Black deposit) in D and E. VVG $\times 400$. 

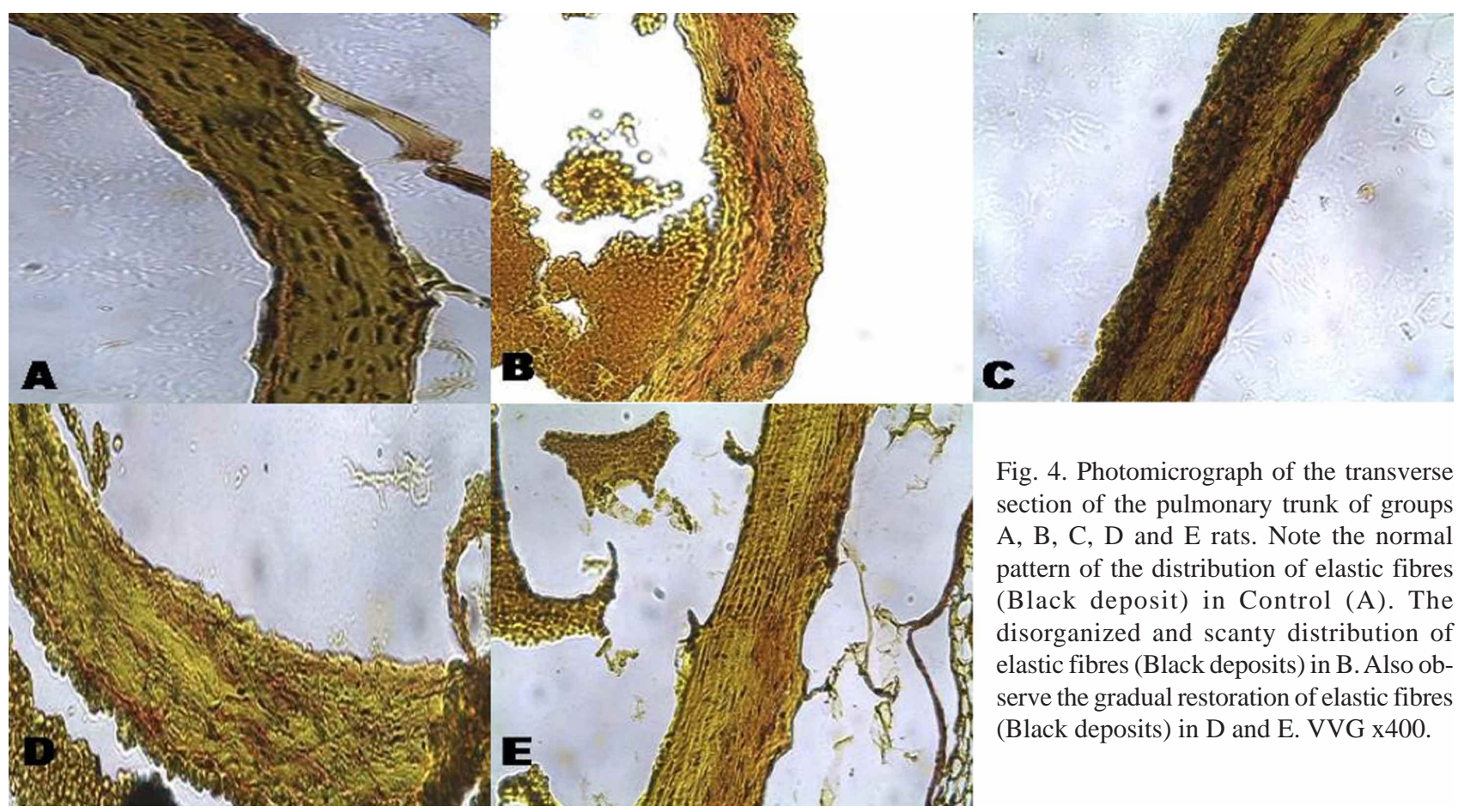

Fig. 4. Photomicrograph of the transverse section of the pulmonary trunk of groups $\mathrm{A}, \mathrm{B}, \mathrm{C}, \mathrm{D}$ and $\mathrm{E}$ rats. Note the normal pattern of the distribution of elastic fibres (Black deposit) in Control (A). The disorganized and scanty distribution of elastic fibres (Black deposits) in B. Also observe the gradual restoration of elastic fibres (Black deposits) in D and E. VVG x400.

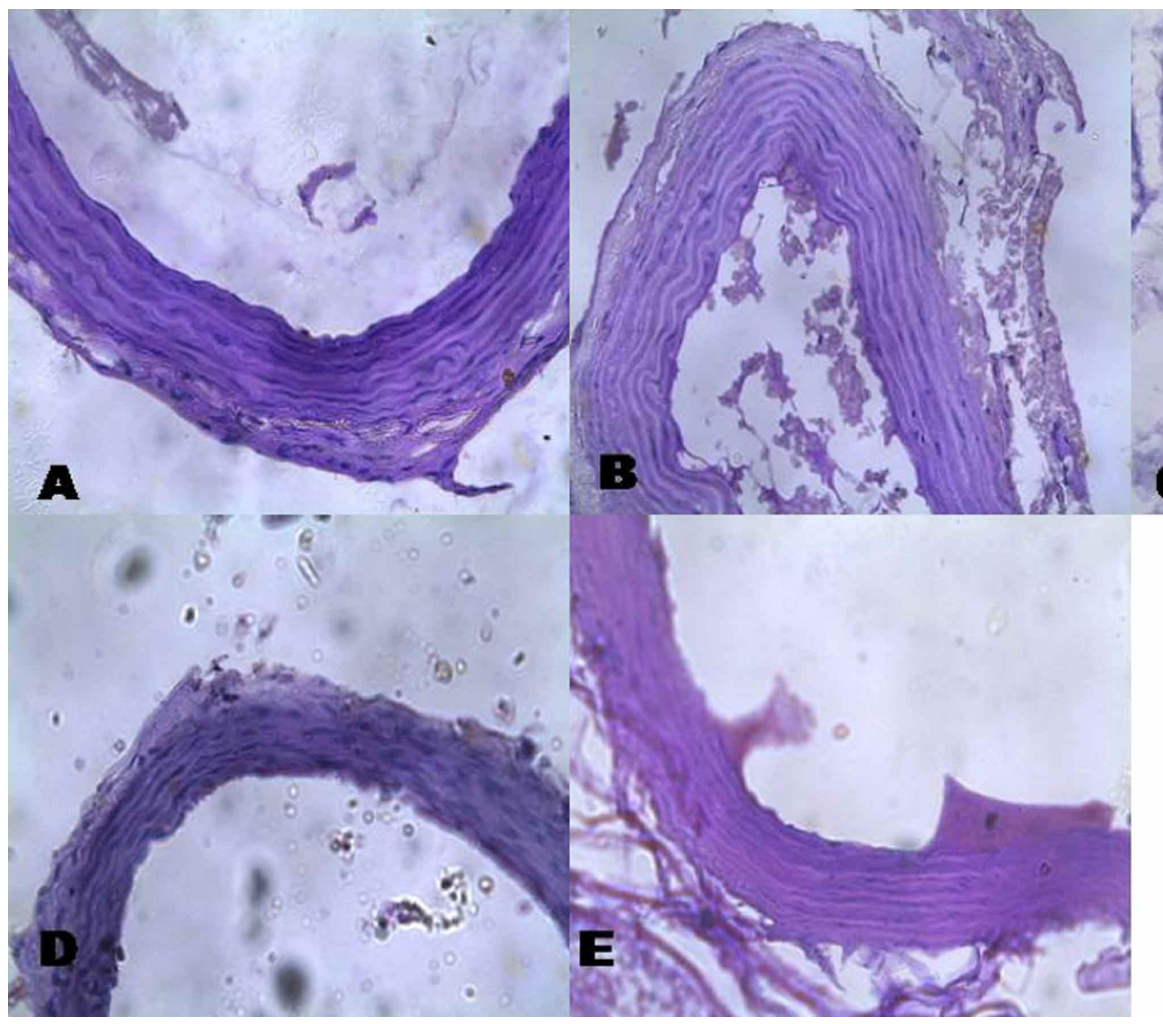

Fig. 5. Photomicrograph of the transverse section of aorta of groups A, $\mathrm{B}, \mathrm{C}, \mathrm{D}$ and $\mathrm{E}$ rats. PAS x100. 


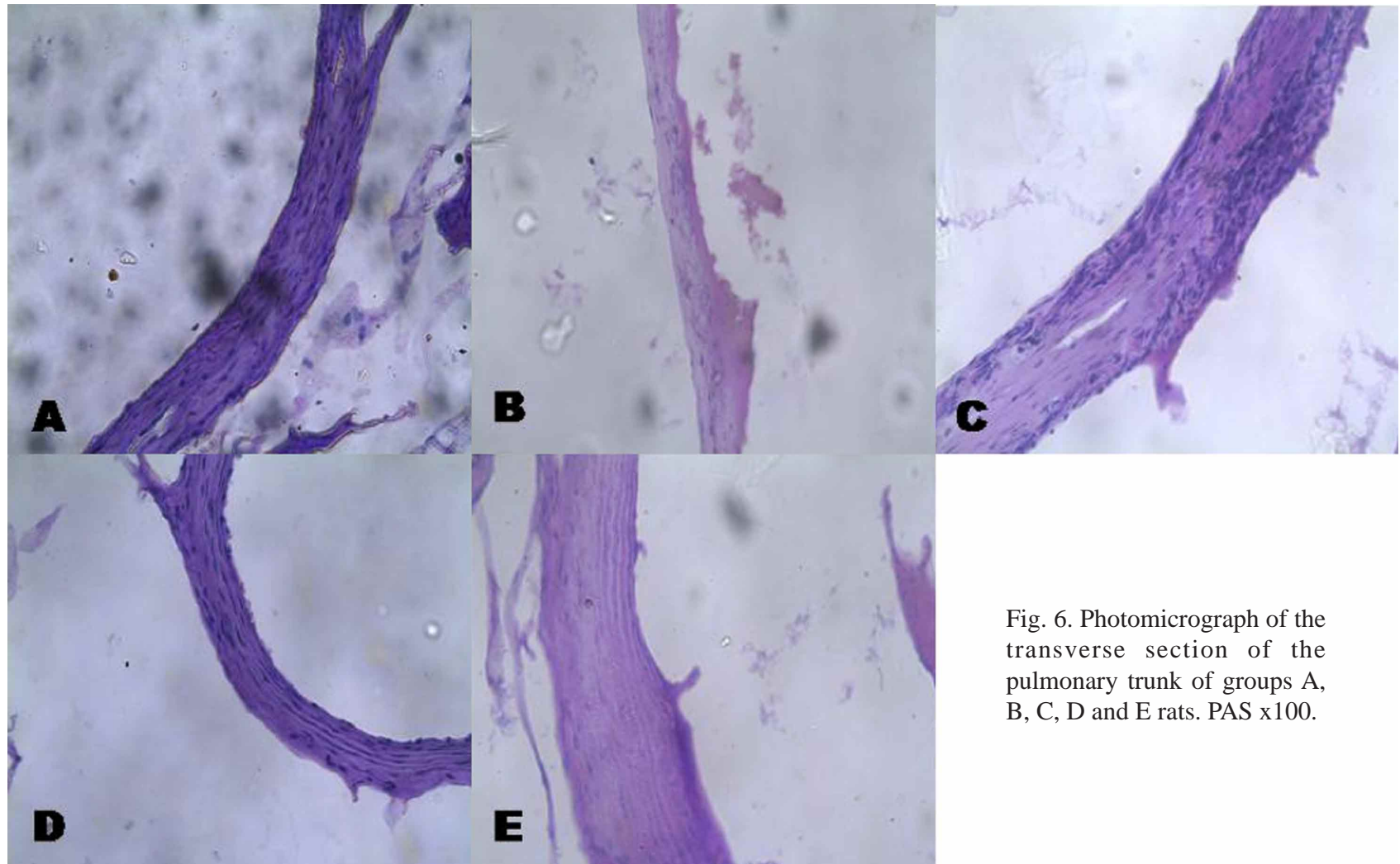

\section{DISCUSSION}

Diabetes has been reported to be associated with profound alterations in biochemical and normal histology leading to an increased risk of coronary heart disease (Huang et al., 1988; Fontbonne et al., 1989; Motta et al., 2001; Maghrani et al., 2004). In this investigation, the extract was observed to present a similar but more potent effect as compared with the antidiabetic drug (glimepiride) in the restoration of morphological derangement.

Histopathologic findings in this study suggest that diabetes may present lipid build up within the vessels, which could form atherosclerotic plaques thus blocking the free flow of blood. This observation is consistent with previous studies (Komolafe, 2008; Kerkeni et al., 2006; Wald et al., 2002). These effects were abrogated with the administration of $M$. charantia extract and glimepiride for four weeks. This suggests that $M$. charantia exhibit vascular protective potential possibly via an anti-atherogenic and anti-lipidemic property. Distributions of elastic fibres was observed to be sparsely distributed as evident by the staining intensity in the walls of the aorta and pulmonary trunk of diabetic rats when compared with the control group. This observation suggests a reduction in the tensile strength and elasticity of these vascular structures and this could lead to the rupture of the arterial wall. Administration of M. charantia and glimperide gradually restored the integrity of these fibres there by reducing the susceptibility to cardiovascular complications such as stroke syndrome and hypertension. Histochemical findings suggest accumulation of glycogen deposit in diabetic rats. In general, glycogen accumulation is an anatomic indicator of a deranged carbohydrate metabolism in alloxan-diabetes which probably reflects the hyperglycaemia (Newell \& Kurimoto, 1963). Glycogen is synthesized in the body in a reaction beginning with glucose1-phosphate which is converted to uridine diphosphate glucose (UDPG) and then to glycogen in reactions catalysed by the enzyme UDPG glycogen-transferase, and the branching enzyme (amylo-1, 4>1, 6 transglucosidase). The reduction in the PAS staining intensity is reflective of reduced glycogen content in the group treated with $M$. charantia and glimepiride for four weeks (Newell \& Kurimoto). All these evidences suggest vascular protective effects of M. charantia against anatomical derangements observed in the diabetic group.

Thus the present results showed that the methanolic extract of $M$. charantia has a promising ameliorative effects on vascular complications implicated in STZ induced diabetes in rats. 
KOMOLAFE, O. A.; OFUSORI, D. A.; ADEWOLE, O. S.; AYOKA, A. O. \& BEJIDE, R. Estudio histológico e histoquímico de la aorta y el tronco pulmonar en ratas Wistar diabéticas inducidas por STZ y tratadas con Momordica charantia. Int. J. Morphol., 31(2):716-723, 2013.

RESUMEN: La diabetes mellitus (DM) es una enfermedad metabólica grave con complicaciones micro y macro vasculares que resultan en una significativa morbilidad y mortalidad. El presente estudio investigó los efectos de Momordica charantia (M. charantia) sobre los cambios histológicos de la aorta y el tronco pulmonar en ratas Wistar con diabetes inducida por estreptozotocina. Cuarenta ratas Wistar adultas sanas de ambos sexos fueron asignadas al azar en cinco grupos A, B, C, D y E, 8 ratas cada grupo. El grupo A fue control (ratas normales); el grupo B fue de ratas diabéticas inducidas experimentalmente; el grupo C fue de ratas diabéticas tratadas con extractos metanólicos de M. charantia por dos semanas (grupo de retirada); grupo D fue de ratas diabéticas tratadas con extractos metanólicos de $M$. charantia durante cuatro semanas, y el grupo E fue de ratas diabéticas tratadas con glimepirida durante cuatro semanas. Los tejidos obtenidos se incluyeron en parafina y se tiñeron con técnica de rutina y tinciones especiales. Los resultados histológicos revelaron alteraciones morfológicas en la aorta y el tronco pulmonar de las ratas diabéticas. El análisis histoquímico reveló también la deposición anormal de glucógeno en estos vasos de ratas diabéticas. Tanto $M$. charantia y glimperida atenuaron las alteraciones morfológicas y redujeron los depósitos de glucógeno. En conclusión, la M. charantia tiene un efecto de mejora prometedor sobre los cambios en la morfología de la aorta y el tronco pulmonar en ratas Wistar diabéticas inducidas por STZ y, por extensión, pueden ser relevantes en el manejo de alteraciones cardiovasculares asociadas con la DM.

PALABRAS CLAVE: Diabetes; Momordica charantia; Histológia; Histoquímica; Aorta; Tronco pulmonar.

\section{REFERENCES}

Akhtar, M. S.; Athar, M. A. \& Yaqub, M. Effect of Momordica charantia on blood glucose level of normal and alloxandiabetic rabbits. Planta Med., 42(3):205-12, 1981.

Braca, A.; Siciliano, T.; D'Arrigo, M. \& Germanò, M. P. Chemical composition and antimicrobial activity of Momordica charantia seed essential oil. Fitoterapia, 79(2):123-5, 2008.

Fontbonne, A.; Eschwège, E.; Cambien, F.; Richard, J. L.; Ducimetière, P.; Thibult, N.; et al. Hypertriglyceridaemia as a risk factor of coronary heart disease mortality in subjects with impaired glucose tolerance or diabetes. Results from the 11year follow-up of the Paris Prospective Study. Diabetologia, 32(5):300-4, 1989.

Grundy, S. M.; Benjamin, I. J.; Burke, G. L.; Chait, A.; Eckel, R. H.; Howard, B. V.; et al. Diabetes and cardiovascular disease: a statement for healthcare professionals from the American Heart Association. Circulation, 100(10):1134-46, 1999.

Huang, T. M.; Lee-Huang, S.; Huang, P. L. \& Chen, H. C. Studies on antiviral activity of the extract of Momordica charantia and its active principle.Virologica, 5(4):367-73, 1988.

Jarrett, R. J. Cardiovascular disease and hypertension in diabetes mellitus. Diabetes Metab. Rev., 5(7):547-58, 1989.

Kerkeni, M.; Addad, F.; Chauffert, M.; Chuniaud, L.; Miled, A.; Trivin, F.; et al. Hyperhomocysteinemia, paraoxonase activity and risk of coronary artery disease. Clin. Biochem., 39(8):8215,2006

Komolafe, O. A. Effects of streptozotocin induced diabetes mellitus on the aorta, pulmonary trunk and left ventricle of rattus norvegicus. M.Sc. Thesis. Obafemi Awolowo University, IleIfe, Osun State, Nigeria, 2008.

Maghrani, M.; Lemhadri, A.; Zeggwagh, N. A.; El Amraoui, M.; Haloui, M.; Jouad, H. \& Eddouks, M. Effects of an aqueous extract of Triticum repens on lipid metabolism in normal and recent-onset diabetic rats. J. Ethnopharmacol., 90(2-3):3317, 2004.

Malone, J. I.; Schocken, D. D.; Morrison, A. D. \& Gilbert-Barness, E. Diabetic cardiomyopathy and carnitine deficiency. J. Diabetes Complications, 13(2):86-9, 1999.

Mir, S. H.; Darzi, M. M.; Ahmad, F.; Chishti, M. Z. \& Mir, M. S. The Influence of Glimepiride on the Biochemical and Histomorphological Features of Streptozotocin-Induced Diabetic Rabbits. Pak. J. Nutr., 7(3):404-7, 2008.

Miura, T.; Ichiki, H.; Hashimoto, I.; Iwamoto, N.; Kato, M.; Kubo, M.; et al. Impairment of insulin-stimulated GLUT4 translocation in skeletal muscle and adipose tissue in the Tsumura Suzuki obese diabetic mouse: a new genetic animal model of type 2 diabetes. Eur. J. Endocrinol., 145(6):785-90, 2001.

Motta, M.; Giugno, I.; Bosco, S.; Pistone, G.; Ruello, P.; Maugeri, D. \& Malaguarnera, M. Serum lipoprotein(a) changes in acute myocardial infarction. Panminerva Med., 43(2):77-80, 2001.

Nagasawa, H.; Watanabe, K. \& Inatomi, H. Effects of bitter melon (Momordica charantia) or ginger rhizome (Zingiber offifinale Rosc.) on spontaneous mammary tumorigenesis in SHN mice. Am. J. Clin. Med., 30(2-3):195-205, 2002. 
KOMOLAFE, O. A.; OFUSORI, D. A.; ADEWOLE, O. S.; AYOKA, A. O. \& BEJIDE, R. Histological and histochemical studies of the aorta and pulmonary trunk in STZ-induced diabetic wistar rats treated with Momordica charantia. Int. J. Morphol., 31(2):716-723, 2013.

Newell, F. W. \& Kurimoto, S. Histochemistry of the retina in the alloxan-diabetic rat. Br. J. Opthamol., 47:596-600, 1963.

Nicholas, L. B.; Kolb, Y. \& Prinssen, E. P. A combined marble burying locomotor activity test in mice: a practical screening test with sensitivity to different classes of anxiolytics and antidepressants. Eur. J. Pharmacol., 547(1-3):106-15, 2006.

Platel, K. \& Srinivasan, K. Plant foods in the management of diabetes mellitus: vegetables as potential hypoglycaemic agents. Nahrung, 41(2):68-74, 1997.

Raman, A. \& Lau, C. Anti-diabetic properties and phytochemistry of Momordica charantia L. (Cucurbitaceae). Phytomedicine, 2(4):349-62, 1996.

Sarkar, S.; Pranava, M. \& Marita, R. Demonstration of the hypoglycemioc action of Momordica charantia in a validate animal model of diabetes. Pharmacol. Res., 33(1):1-4, 1996.

Tan, F. J.; Fire, A. Z. \& Hill, R. B. Regulation of apoptosis by C. elegans CED-9 in the absence of the C-terminal transmembrane domain. Cell Death Differ., 14(11):1925-35, 2007.

The Diabetes Control and Complications Trial Research Group. The effect of intensive treatment of diabetes on the development and progression of long-term complications in insulin-dependent diabetes mellitus. N. Engl. J. Med., 329(14):977-86, 1993.

Vats, V.; Yadav, S. P. \& Grover, J. K. Ethanolic extract of Ocimum sanctum leaves partially attenuates streptozotocin-induced alterations in glycogen content and carbohydrate metabolism in rats. J. Ethnopharmacol., 90(1):155-60, 2004.

Wald, D. S.; Law, M. \& Morris, J. K. Homocysteine and cardiovascular disease: evidence on causality from a metaanalysis. BMJ, 325(7374):1202, 2002.

\author{
Correspondence to: \\ O. A. Komolafe \\ Department of Anatomy and Cell Biology \\ Faculty of Basic Medical Sciences \\ Obafemi Awolowo University \\ Ile-Ife, Osun-State \\ NIGERIA
}

Tel: +23480334998833

Email: bkomolaf@yahoo.com

Received: 26-04-2012

Accepted: 25-02-2013 